\title{
The Basement of the Andean Frontal Cordillera in the Cordón del Plata (Mendoza, Argentina): Geodynamic Evolution
}

\author{
Nemesio Heredia ${ }^{1}$, Pedro Farias ${ }^{2}$, Joaquín García-Sansegundo ${ }^{2}$, Laura Giambiagi ${ }^{3}$
}

\author{
${ }^{1}$ Instituto Geológico y Minero de España, C/Matemático Pedrayes 25, E33205 Oviedo, España. \\ n.heredia@igme.es \\ ${ }^{2}$ Facultad de Geología, Universidad de Oviedo. C/ Jesús Arias de Velasco s/n, E33205 Oviedo, España. \\ pfarias@geol.uniovi.es; j.g.sansegundo@geol.uniovi.es \\ ${ }^{3}$ CONICET-IANIGLA, Parque San Martín s/n, 5500, Mendoza, Argentina. \\ lgiambia@lab.cricyt.edu.ar
}

\begin{abstract}
The Andean Paleozoic basement of the Cordón del Plata (Argentina) consists of two sets of rocks showing different stratigraphy, structure and metamorphism. The lower one is represented by the pre-Carboniferous (Devonian?) Vallecitos beds. These rocks have been affected by folds and associated cleavage, developed under low-grade metamorphic conditions and related to the Chanic orogenic event of the Famatinian Orogenic Cycle (Upper Devonian-Lower Carboniferous). The Vallecitos beds is pre-orogenic to the Chanic deformation event and must have been deposited in a fore-arc basin located on the active margin of Chilenia, before its collision with the passive margin of Gondwana. The upper set unconformably rests on the Vallecitos beds and consists of the Late Carboniferous El Plata Formation, and the Río Blanco Conglomerates, probably Late Carboniferous-Permian in age. These rocks have been affected by eastdirected thrusts and associated folds formed under very low-grade to non-metamorphic conditions. This deformation can be related to the San Rafael phase (Gondwanan Orogen). The El Plata Formation was deposited in an extensional back-arc basin while the Río Blanco conglomerates must have been deposited in a retro-arc basin, both of them on the active margin of Gondwana. The Choiyoi Group, essentially volcanic and Permo-Triasic in age, rests unconformably on the previously described successions and was deposited in an extensional setting (pre-orogenic stage) associated with the beginning of the Andean Cycle. This cycle lead to the uplift of the Frontal Cordillera during the Cenozoic and the deposition of thick continental units at the base of the Cordón del Plata in Neogene-Quaternary times.
\end{abstract}

Keywords: Paleozoic Basement, Chanic Orogeny, Gondwanan Orogeny, Geodynamic Evolution, Frontal Cordillera, Andes, Argentina.

RESUMEN. El Basamento de la Cordillera Frontal de los Andes en el Cordón del Plata (Mendoza, Argentina): Evolución Geodinámica. El basamento paleozoico de los Andes, que aflora en el Cordón del Plata (Argentina), está formado por dos conjuntos de rocas con diferente estratigrafía, estructura y metamorfismo. El conjunto inferior está representado por las capas de Vallecitos, de edad precarbonífera (posiblemente devónica). Estas rocas se encuentran afectadas por pliegues y clivajes asociados, formados en condiciones metamórficas de bajo grado y relacionados con la Orogenia Chánica del Ciclo Famatiniano (Devónico Superior-Carbonífero Inferior). Las capas de Vallecitos tienen un carácter preorogénico y se habrían depositado en una cuenca de antearco situada sobre un margen activo de Chilenia, antes de su colisión con el margen pasivo de Gondwana. El conjunto superior, discordante sobre las capas de Vallecitos, está constituido por la Formación El Plata, de edad Carbonífero Superior, y los Conglomerados de Río Blanco, discordantes sobre la anterior, de probable edad Carbonífero Superior-Pérmico. Todas estas rocas han sido afectadas por corrimientos y pliegues asociados, vergentes al este, generados en condiciones epimetamórficas y relacionables con la Fase Orogénica San Rafael del Ciclo Gondwánico. La Formación El Plata se depositó en una cuenca de trasarco mientras que los Conglomerados de Río Blanco lo hicieron en una cuenca de antepaís de retroarco, ambas sobre el margen activo de Gondwana. Discordantemente, sobre todas las rocas antes mencionadas se apoya el Grupo Choiyoi, de naturaleza fundamentalmente volcánica y edad pérmico-triásica, que ha sido depositado en un contexto extensional preorogénico, característico del comienzo del Ciclo Andino. Este ciclo culmina con el levantamiento de la Cordillera Frontal durante el Cenozoico y el depósito de espesas secuencias continentales neógeno-cuaternarias a los pies del Cordón del Plata.

Palabras clave: Basamento Paleozoico, Orogenia Chánica, Orogenia Gondwánica, Evolución geodinámica, Cordillera Frontal, Andes, Argentina. 


\section{Introduction}

The Cordón del Plata is a mountain range located $50 \mathrm{~km}$ west of Mendoza (Argentina) and is part of the Frontal Cordillera of the Andes (Groeber, 1938) (Fig. 1).

The Frontal Cordillera contains a Paleozoic basement constituted by sedimentary, metamorphic and igneous rocks (Fig. 2), which was strongly deformed during the Famatinian and Gondwanan orogenic cycles (Ramos, 1988) and is intruded by Upper Paleozoic granitoids. An Andean cover lies unconformably over the Paleozoic basement, and is constituted by Permo-Triassic and Cenozoic sedimentary, volcanic and volcaniclastic rocks (Fig. 2), intruded by Mesozoic and Cenozoic granitoids. This cover was deformed in Cenozoic times, during the Andean Orogenic Cycle. The main Andean orogeny uplift is linked with the Nazca plate subhorizontal subduction, located between $27^{\circ}$ and $33^{\circ} 30^{\prime}$ 'S latitude along the Pampean flat-slab segment (Gutscher et al., 2000). The absence of recent volcanism in the Pampean flat-slab segment allows the observation of the Paleozoic, Mesozoic and Cenozoic rocks and structures.

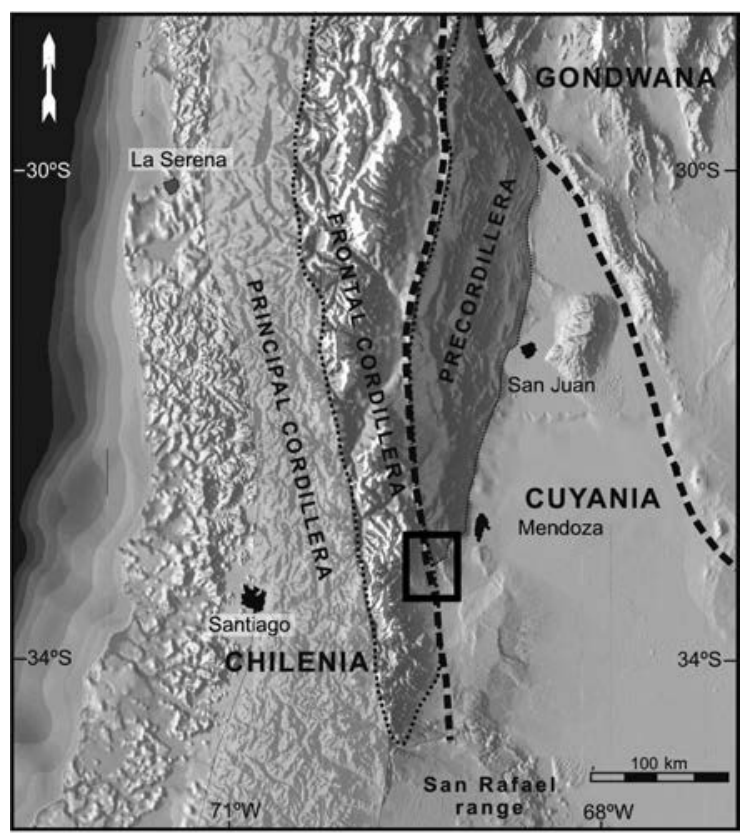

FIG. 1. Morphostructural map of the Andes between $29^{\circ}$ and $35^{\circ} \mathrm{S}$, showing the location of the Paleozoic terranes and sutures. The box indicates the location of the study area shown in figure 2. Based on Ramos (2004).
The study area is more than 6,000 $\mathrm{m}$ high and contains an extensive outcrop of the Paleozoic basement of the Andes (Fig. 3), formed by two sets of rocks with different deformational features and metamorphic grades. Permo-Triassic volcanic rocks of the Choiyoi Group and Cenozoic sedimentary rocks unconformably overlie this basement (Figs. 2 and 4).

The N-S trending La Carrera fault system (Caminos, 1965; Polanski, 1972), whose main faults from west to east are: Arenal, Médanos and Río Blanco (Fig. 2), has been traditionally recognized as responsible for the Andean uplift of this range, although the first development of these structures has been recently assigned to the Permian San Rafael phase of the Gondwanan Orogen (Giambiagi et al., 2011). This fault system, composed by several N-S trending thrusts, uplifted the basement rocks of the Cordón del Plata range during the Cenozoic Andean Orogen. The easternmost faults of this system (between Médanos and Río Blanco faults) affect the Neogene synorogenic deposits (Folguera et al., 2003; Casa, 2005), and show evidence of Quaternary activity (Fauqué et al., 2000; Casa, 2005).

The aim of this study is to characterize the basement rocks outcroping in the eastern slope of the Cordón del Plata and compare them with studied sequences of neighbouring areas. By analyzing the deformation history and metamorphism, we attempt to establish the tectono-stratigraphic evolution of these rocks and fit them into a coherent evolution model for the Andes during the Late Paleozoic.

\section{Stratigraphy}

There are four main stratigraphic units, separated by unconformities in the study area (Figs. 2 and 4):

I. The oldest unit consists of centimeter to decimeter scale, well-stratified beds of dark quartzites and laminated shales (Fig. 5A), where cross-and flaser-laminations can often be recognized. Meter thick beds of clast-supported conglomerates, including centimeter-sized clasts of quartz, plutonic, volcanic and other metamorphic rocks can occasionally be observed. Until now, no sedimentologic studies have been made on these rocks, although their stratigraphic characteristics could indicate a turbiditic origin.

The age of these rocks is not well known due to the absence of fossils. Based on lithological characteristics and stratigraphic position, this sequence is very 


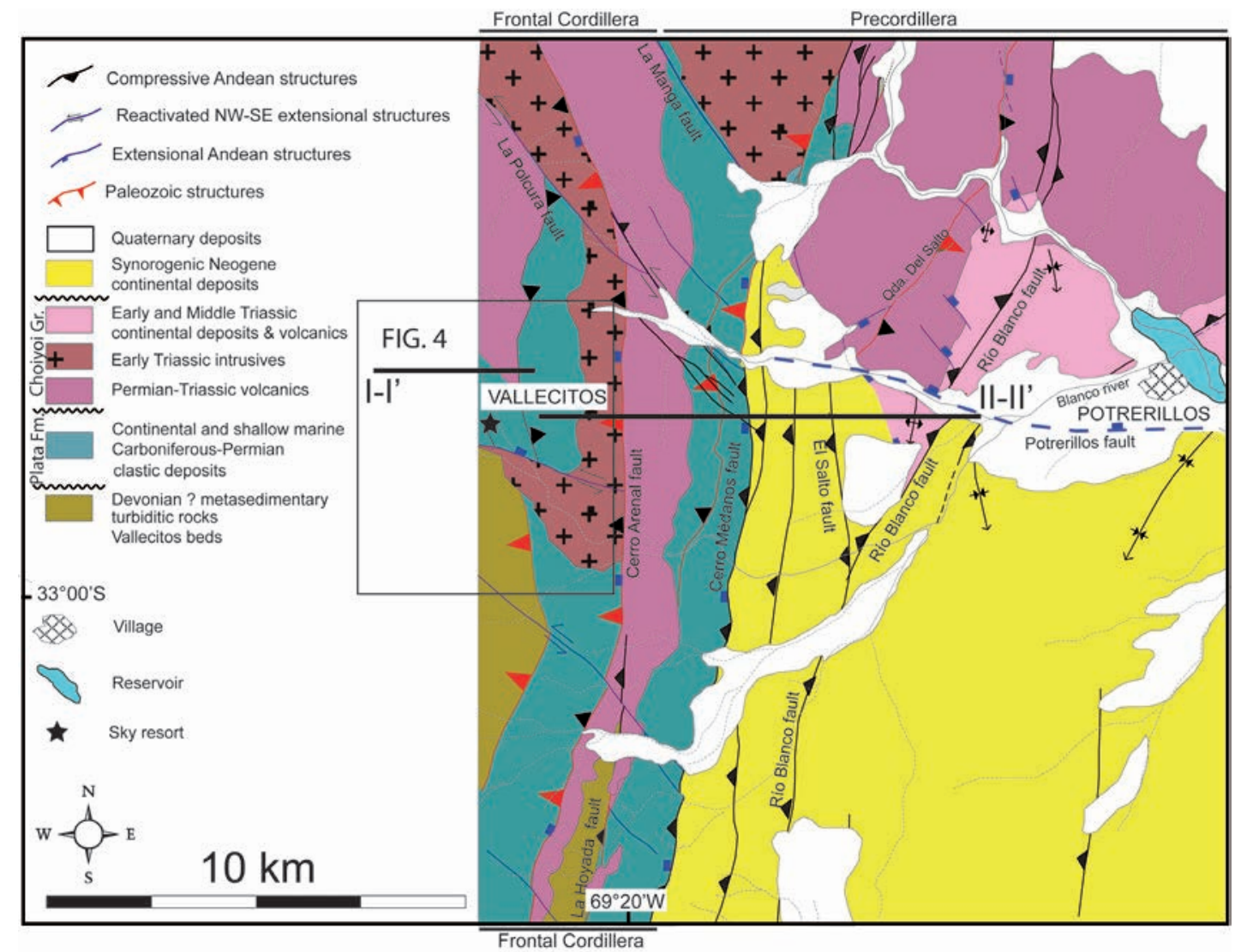

FIG. 2. Geological sketch map of the study area, including the Frontal Cordillera and Precordillera of the Andes. Modified from Folguera et al. (2003).

similar to the Alto Tupungato Formation, described by Polanski (1959) in the western part of the Cordón del Plata massif, which has been assigned to Early Carboniferous or older. However, this formation was attributed to the Late Carboniferous (López Gamundí et al., 1987), which would invalidate this possible correlation. In addition, succesions with similar facies, covered unconformably by Late Carboniferous rocks, have been assigned to the Devonian in the Frontal Cordillera of the San Juan province (Gutiérrez, 1983; Azcuy et al., 1999; Heredia et al., 2002). Recently, south of the study area, Tickyj et al. (2009) have described Late Ordovician beds in the eastern side of the Frontal Cordillera (Las Lagunitas Formation); but their stratigraphic features are different (more slates and lithic sandstone predominance) from those described for the Cordón del Plata area and they could be older. For all these reasons, we provisionally named these rocks as Vallecitos beds and assigned them to the Devonian.
The absence of subaerial volcanism older than Late Carboniferous in the eastern part of the Frontal Cordillera (including the Precordillera), suggests a western origin for the volcanic clasts included in the conglomerates of the Vallecitos beds.

This succesion is intruded by many deformed dykes of quartz and pegmatites of granitic/granodioritic composition, which do not affect the overlying El Plata Formation.

The Vallecitos beds have similar facies to the Devonian succesions described in the central and eastern Precordillera, which are part of the Gualilán Group (Baldis and Sarudiansky, 1975) (Fig. 6). The same Devonian age has been assigned to the Villavicencio and El Codo formations, described in the western part of the Precordillera (Harrington, 1941; Guerstein et al., 1965; Sessarego, 1988; Baldis and Peralta, 1999; Amenabar and di Pasquo, 2004). In contrast to the Vallecitos series, the Gualilán Group has an eastern non-volcanic source area (González Bonorino, 1975), 

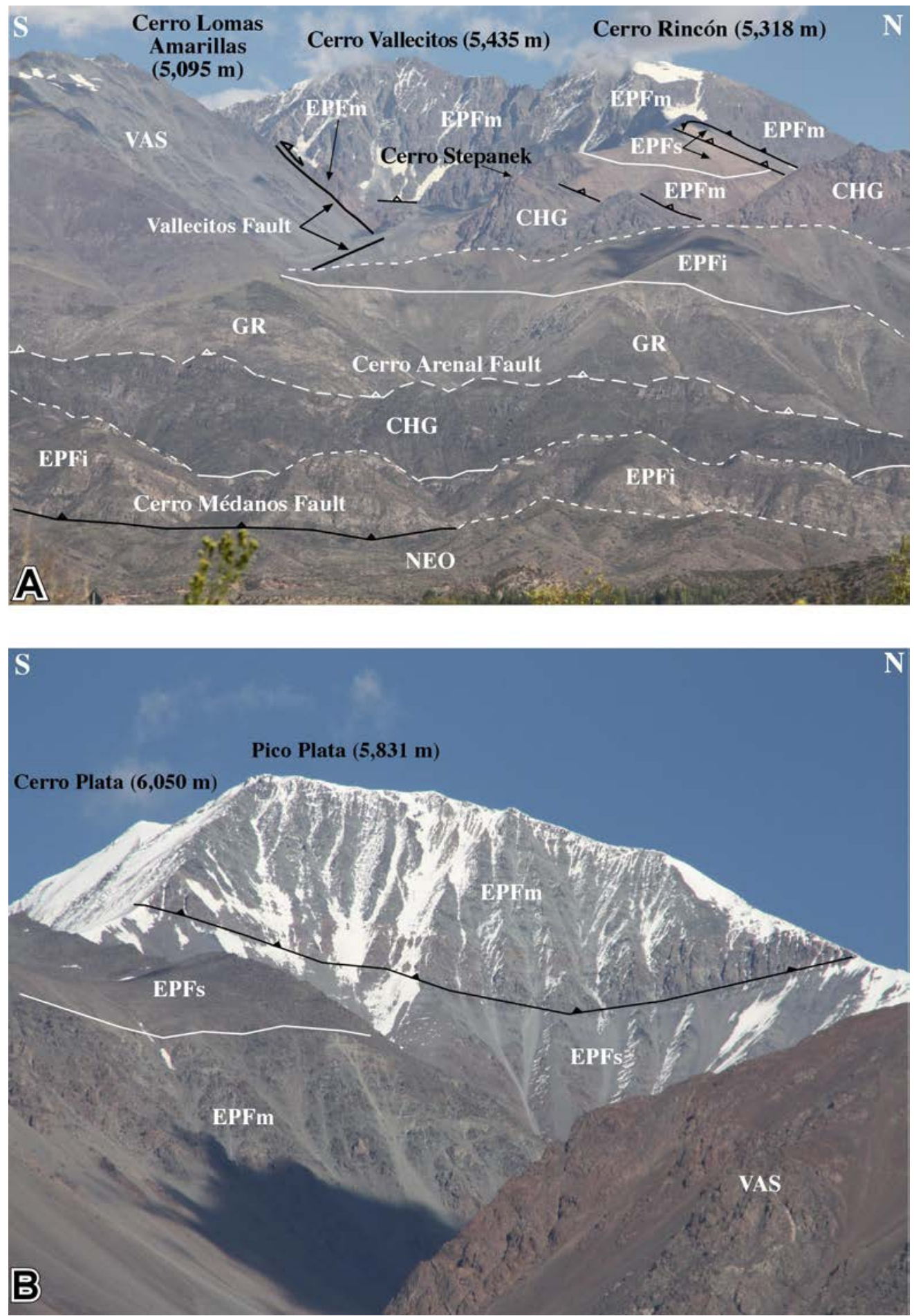

FIG. 3. Photographies showing the main geological features of the east side of the northern (A) and southern (B) Cordón del Plata. VAS: Vallecitos beds; EPF: El Plata Formation; i: lower member; m: middle member; s: upper member; CHG: Choiyoi Group; GR: Cerro Arenal granite; NEO: Neogene deposits. White lines: lithostratigraphic contacts; Dotted white lines: Apparent lithostratigraphic boundaries in the picture; Black triangles: Gondwanan thrust; Blank triangles: Andean thrust. 


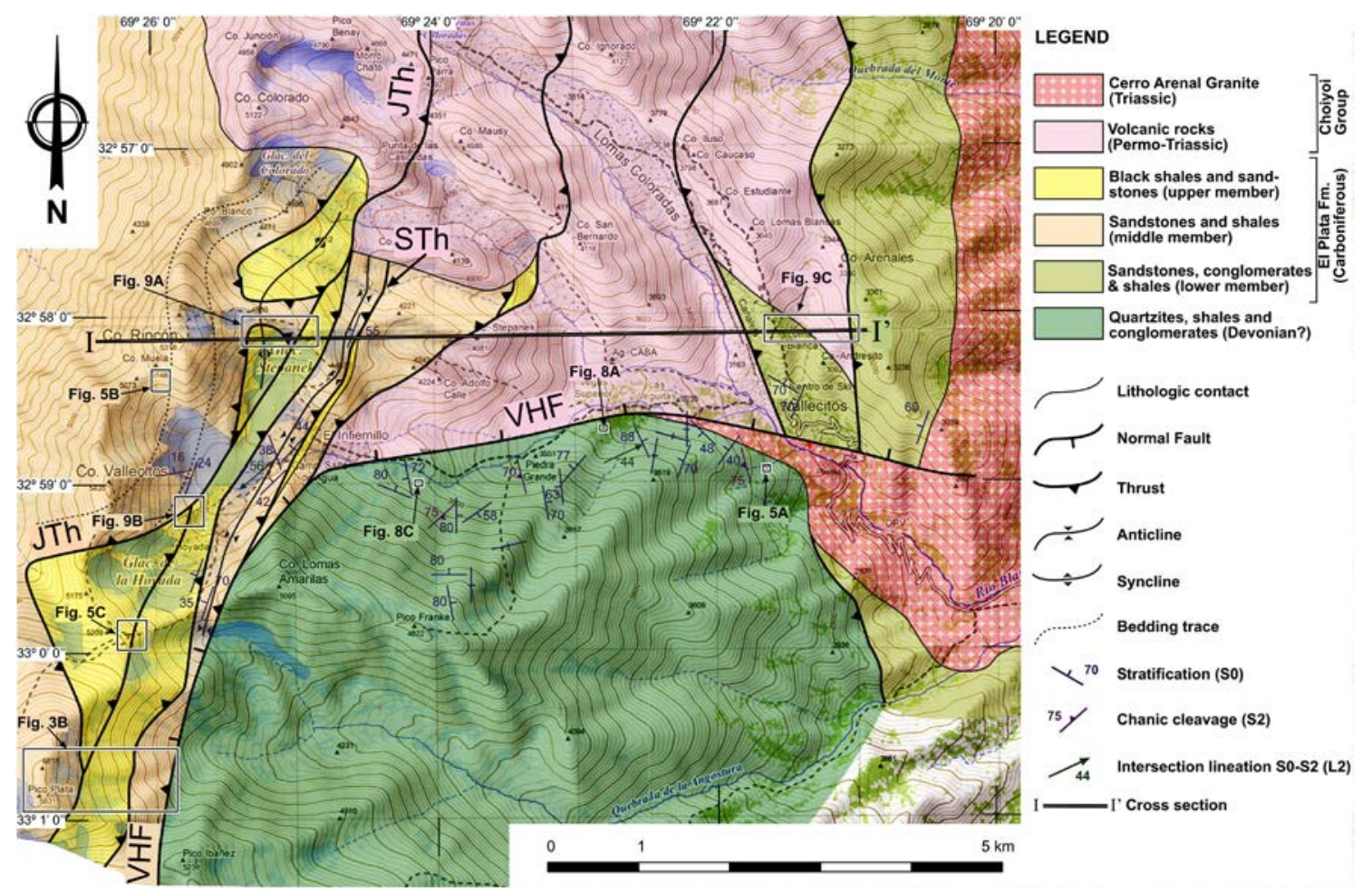

FIG. 4. Geological sketch map of the Frontal Cordillera in the Cordón del Plata area. VHF: Vallecitos-La Hoyada fault; JTh: La Jaula thrust; STh: El Salto thrust.

which hamper the correlation between the two stratigraphic units. As in the Vallecitos beds, the Ratón Formation from the western Precordillera, included in the Angualasto Group (Early Carboniferous) (Fig. $6)$, contains conglomerates with volcanic clasts of western origin. Although the Agualasto Group and the Vallecitos beds have similar deformational style, these units do not seem to correlate, since the Angualasto Group shows different facies and unconformably overlies the Devonian series (El Codo Formation).

II. A thickening siliciclastic succession rests unconformably over the Vallecitos beds. It is composed of the El Plata Formation (Caminos, 1965, 1979) at the bottom part and the Río Blanco Conglomerates at the top (Fort, 1944; Caminos, 1965).

The El Plata Formation has a thickness of nearly 3,300 $\mathrm{m}$ in the study area, and includes three members (Caminos, 1965):

- The lower member crops out along several bands bounded by thrusts in the lower part of the eastern slope of the Cordón del Plata massif (Fig. 3A) and it can reach a thickness of $1,200 \mathrm{~m}$ in nearby areas. Its lower part consists of conglomerates with plutonic and metamorphic pebbles. In the upper part, the conglomerates change to alternating arkosic and quartz sandstones, interbedded with gray-green shales and some quartzitic microconglomerates. This member is very similar to the Loma de los Morteritos Formation, defined by Polanski (1959) in nearby areas, and is assigned to the Late Carboniferous (Folguera et al., 2003).

- The middle member is almost 1,500 $\mathrm{m}$ thick and is composed of gray medium to coarse-grained quartzitic litarenites, in meter to decimetre thick beds with thin interbedded shales. These rocks form the eastern wall of the Vallecitos and Rincon peaks and the eastsoutheast face of the El Plata peak (Figs. 3 and 5B). - The upper member can exceed 4,000 $\mathrm{m}$ in thickness (Azcuy et al., 1999), although in the study area it does not exceed $600 \mathrm{~m}$ as it is covered by thrusts. This member is mainly composed of shales (Fig. 5C) with centimetre thick intercalations of fine-grained sandstones with ripple lamination towards the top. At its base, it contains a very characteristic carbonaceous shale intercalation that is intensely tectonized. 

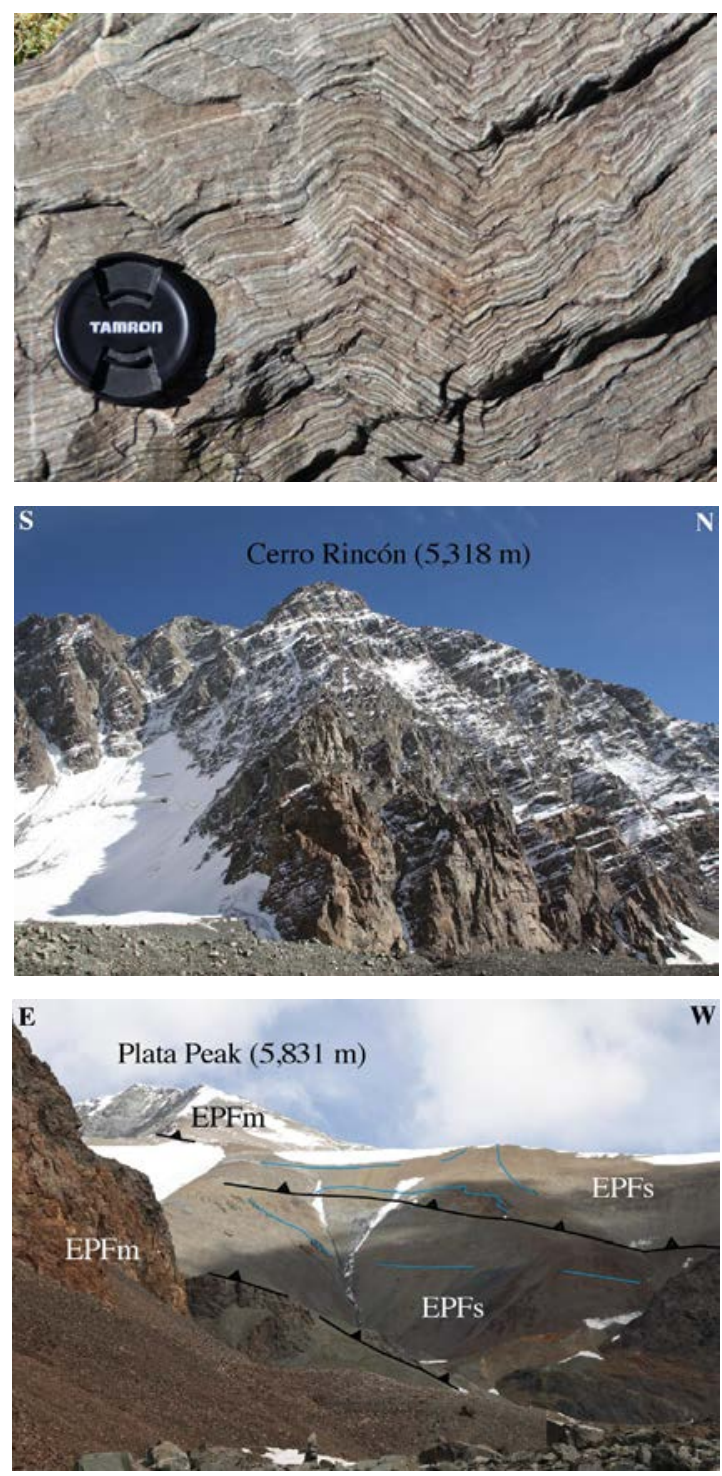

FIG. 5. Photographies of the main Paleozoic stratigraphic units. A. Fine-stratified quartzites of the Vallecitos beds; B. Sandstones of the El Plata Formation middle member; C. Shales and fine-grained sandstones of the El Plata Formation upper member. Note the presence of tectonic duplications in this member. EPF: El Plata Formation; m: middle member; s: upper member.

Freije et al. (1999) described basaltic pillow lavas, up to $5 \mathrm{~m}$ thick, interbedded in the sediments of the El Plata Formation. The sedimentary environment of the El Plata Formation ranges from shallow marine platform facies in the lower member to fluvial and deltaic in the middle and upper ones respectively (Folguera et al., 2003).
The Río Blanco Conglomerates (Fort, 1944; Caminos, 1965) crop out in the La Manga Quebrada, located in the northern part of the study area (Fig. 2). Due to their moderate thickness of 20-80 m, they have not been represented on the geological map of the figure 2. These conglomerates contain metamorphic, sedimentary and volcanic pebbles and unconformably overlie the El Plata Formation, being unconformably covered by the Tambillos Formation (Choiyoi Group) of lower Permian age (Cortés et al., 1997).

The El Plata Formation is similar in lithology and stratigraphic characteristics to the Agua Negra Formation (Polanski, 1970), which outcrops in the Frontal Cordillera to the west of San Juan province (Fig. 6). Moreover, the lower part of the San Ignacio Formation (Carboniferous-Permian), which overlies unconformably the Agua Negra Formation (Heredia et al., 2002; Busquets et al., 2005), is similar to the Río Blanco Conglomerates (Fig. 6). Both formations, San Ignacio and Río Blanco, could represent an alluvial fan system in which volcanic levels are interbedded.

III. The Paleozoic basement is unconformably covered by the Choiyoi Group volcanics (Figs. 4, 7 and 9C) of Permian-Triassic age (Groeber, 1946; Rolleri and Criado, 1969). In the study area, this group is composed of acidic to intermediate volcanic and volcaniclastic rocks as well as plutonic or subvolcanic intrusions with the same composition (Cortes et al., 1997). The upper part is composed of sedimentary rocks (only in the Precordillera, Fig. 2), that are mainly constituted by clastic continental deposits with some interbedded volcanic rocks.

The Paleozoic and Early Mesozoic rocks are intruded by Triassic granitoids that produced a thermal metamorphism with amphibole and biotite hornfels. The outcrops of these granitoids show an elongated N-S trend (Fig. 2 and 4), running parallel to the Andean structures. Caminos et al. (1979) dated Cerro Arenal and Cerro Médanos (Precordillera) batholiths in the study area as Middle Triassic (K-Ar ages of $237 \pm 10$ and $244 \pm 10$ Ma respectively).

IV. Finally, in the foothills of the Cordón del Plata massif, Cenozoic (Neogene) conglomerates, sandstones and shales of continental origin rest unconformably on the rocks described above. They are part of the alluvial fans that drain the relief of the Frontal Cordillera (Figs. 2 and 3A) and they represent the synorogenic deposits of the Andean Cycle. 


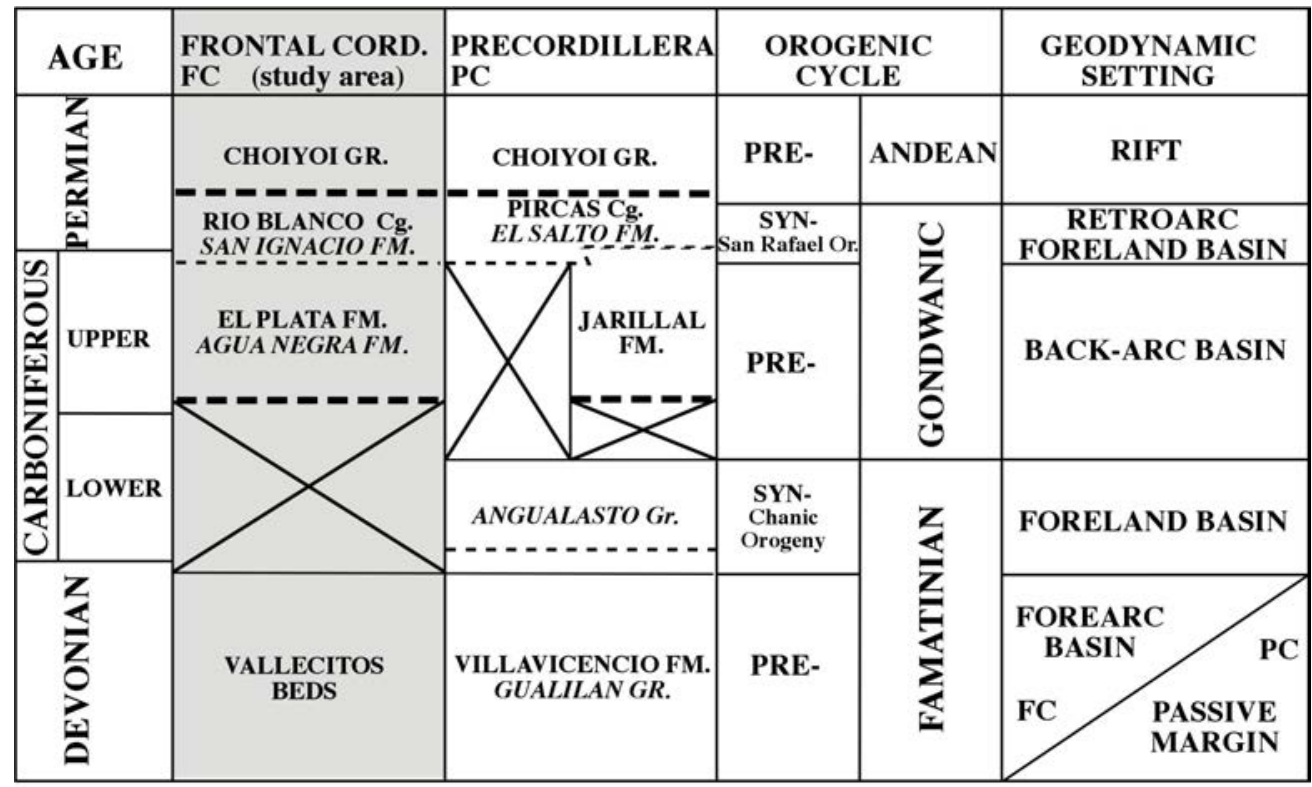

- - - - Main Unconformities

- - - - Synorogenic Unconformities

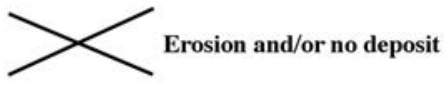

FIG. 6. Stratigraphic correlations panel. Fm: formation; Gr: group; Or: orogeny; Cg: conglomerates; In Italics: the equivalent litostratigraphic units of nearby areas.

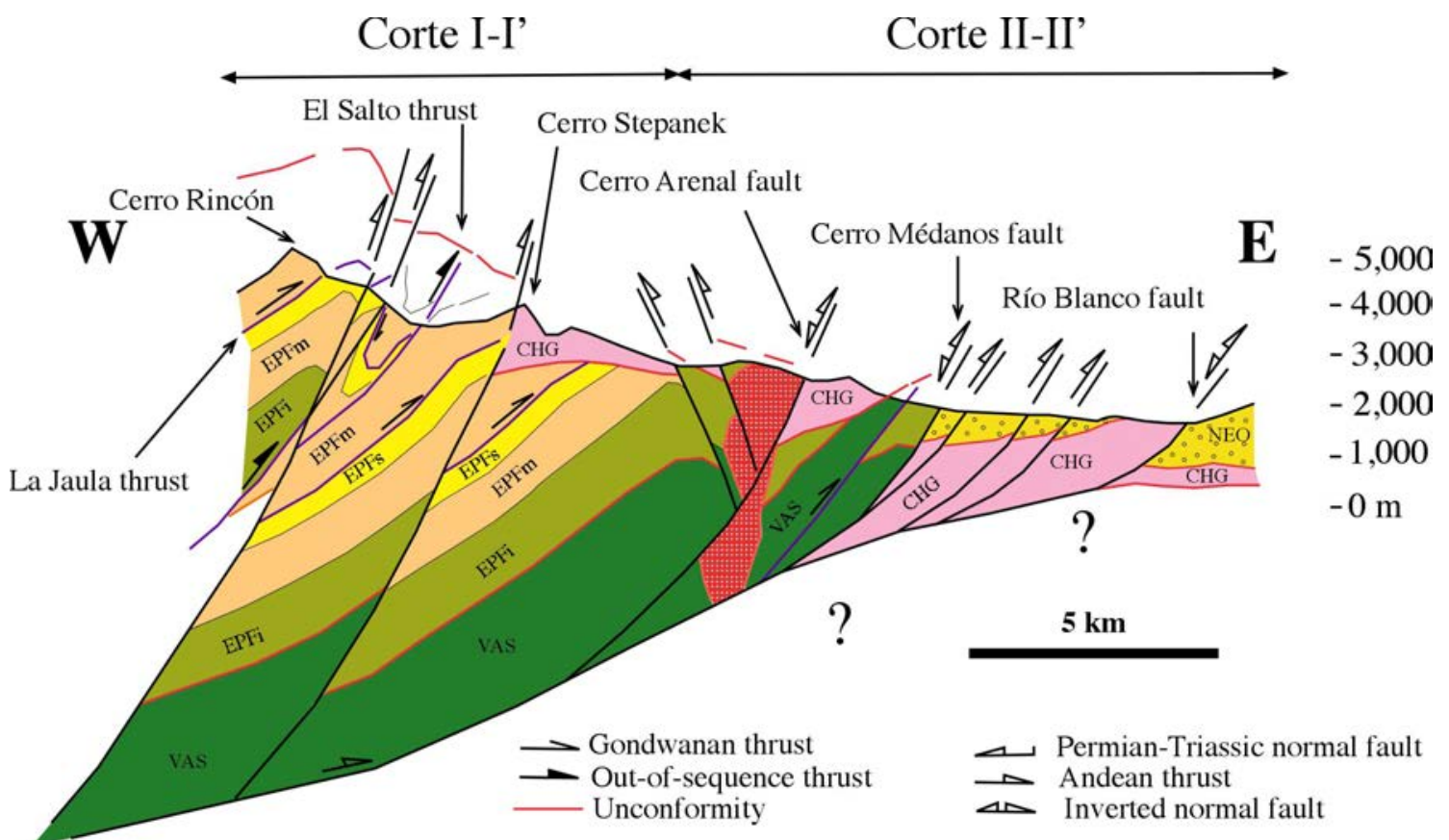

FIG. 7. Geological cross section. Location in Fig. 2 (II-II') and 4 (I-I'). Legend for stratigraphic units located in figure 4. Horizontal and vertical scale is the same. VAS: Vallecitos beds; EPF: El Plata Formation; i: lower member; m: middle member; s: upper member; CHG: Choiyoi Group; GR: Cerro Arenal granite; NEO: Neogene deposits. 


\section{Structure and Metamorphism}

The pre-Andean basement of the Cordón del Plata massif is affected by Paleozoic to Cenozoic structures, developed during four deformation episodes. The oldest one (I) took place in pre- to Early Carboniferous times under low-grade metamorphic conditions and can be linked to the Famatinian Orogenic Cycle. The second episode (II), Late Carboniferous-Permian in age, was developed in very low grade to non-metamorphic conditions during the Gondwanan Cycle. The last two episodes (III and IV) belong to the Andean Cycle and took place without metamorphism.

\subsection{Pre-Late Carboniferous Famatinian structures}

This deformation episode only affects Vallecitos beds and is characterized by centimeter to decimeter scale close to tight subvertical folds. These structures are folding an S1 slaty cleavage (Figs. 8A and B), which forms an angle lower than $10^{\circ}$ with bedding (Fig 8A). In the shaly layers, $\mathrm{S} 1$ is defined by shape preferred orientation of chlorite and muscovite porphyroblasts and quartz crystals. In the quartzites, S1 is only recognized by the orientation of some phyllosilicates and opaque minerals (Fig. 8C), and can be classified as a spaced disjunctive cleavage. In the microlithons, quartz is accompanied by plagioclase and K-feldspar. The slaty cleavage (S1) is usually crenulated (Figs. $8 \mathrm{~A}$ and $\mathrm{C}$ ) and sometimes develops a crenulation cleavage (S2). At the microscopic scale, S2 is a rough, anastomosing and discontinuous crenulation cleavage (Fig. 8C), associated to the folds (Fig. 8A). Both foliations, S1 and S2, are sometimes partially obliterated by the growth of biotite and amphibole associated to the thermal Triassic metamorphism, related to magmatic activity.

\subsection{Late Carboniferous-Permian Gondwanan structures}

These structures are represented by westward dipping and east-directed thrusts (Fig. 4 and 7) with associated subhorizontal N-S meter sized folds. Some of the folds have an associated rough cleavage in shaly beds. The thrust detachment is located in the basal member of the El Plata Formation, in the easternmost sector of the El Plata range, but in the western part it develops in the basal sandstones
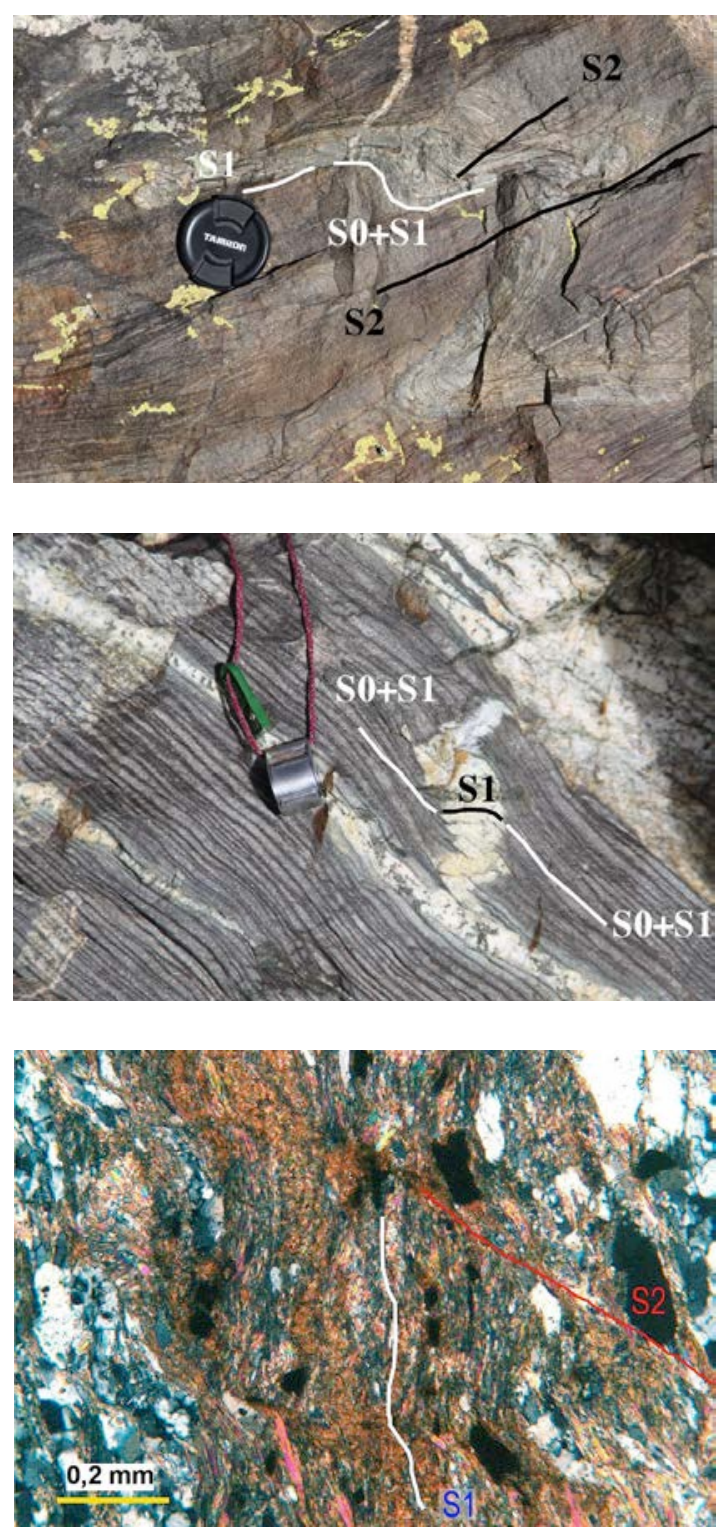

FIG. 8. Photographies of the main Chanic macro- and microstructures. A. Metric-scale fold with a S2 associated cleavage and folding a previous S1; B. S1 affecting small quartz dyke; C. Microstructure of the Vallecitos beds quartzites showing the S1 and S2 traces. Crossed polars.

of the middle member (Figs. 3B, 4 and 7). Another detachment is located at the base of the upper slate member of the El Plata Formation (Fig. 5C, 7 and 9B). Some of these thrusts produce a kilometer scale shortening, which is greater than $5 \mathrm{~km}$ in the La Jaula thrust. An out-of-sequence thrust, El Salto Thrust, cuts a previous one producing the 
folding of the La Jaula thrust (Figs. 3, 4, 7 and 9A) and is covered unconformably by the Choiyoi Group, allowing the dating of these structures as pre-Andean (Fig. 4).

\subsection{Andean extensional structures}

From the Late Permian to the Middle Triassic this part of the Frontal Cordillera was affected by extensional tectonics (Mpodozis and Ramos, 1989; Uliana et al., 1989; Llambias et al., 1993) that started the Andean Cycle (Heredia et al., 2002). The Permo-Triassic normal faults show a N-S preferred trend, with some segments oriented NESW to NW-SE (Figs. 2, 4 and 10). These faults are contemporaneous with the deposition of the Choiyoi Group, and produced significant variations in its thickness and lithological characteristics (Heredia et al., 2002). The elongated geometry of the Triassic granitoids (Figs. 2 and 4), with the same trend of the normal faults, indicates that their intrusion could be structurally controlled by these faults.

The Vallecitos-La Hoyada normal fault must have developed during this period, as the Choiyoi Group does not exist to the south and east of this structure (Fig. 4). The change in the trend of the fault, from N-S to E-W (Figs. 4 and 10), could be controlled by the presence of pre-Andean structures with the same directions. This fault is very steep in the segment with E-W trend (Vallecitos Fault, Fig. 10), allowing to interpret it as a transfer zone of the Permian-Triassic extensional system, which mainly trends N-S in this area of the Frontal Cordillera (Fig 10).

The Rio Blanco, Cerro Médanos and Cerro Arenal faults (Figs. 2, 3A and 7), located at the eastern border of the Cordón del Plata massif, could also be considered as related with the Permo-Triassic extension (Fig. 10), although they were reactivated and inverted during later Cenozoic compression. In the northern part of the Río Blanco fault, coinciding with the southern outcrops of the Precordillera, the thickness of the Choiyoi Group is similar in both the eastern and western fault walls. However, the Choiyoi Group in the southern part of the fault is very thin, and is only represented by the lower volcanic part, or is even entirely absent in the eastern hanging wall (Fig. 7). This coincidence could be explained by the existence of an E-W trending transfer fault (Fig. 10), which is now covered by Cenozoic rocks (Potrerillos
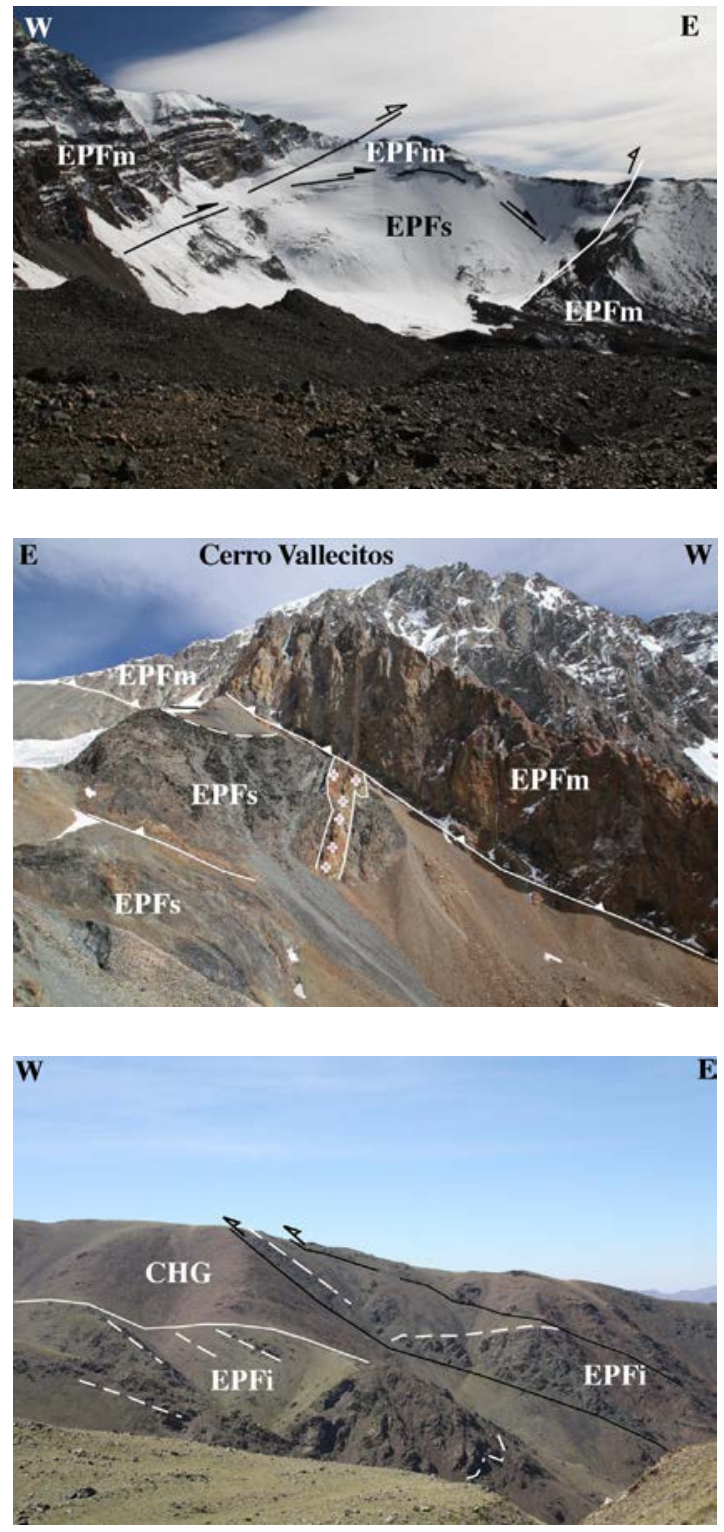

FIG. 9. Photographies of the main Gondwanan and Andean structures. A. Gondwanan thrust (simple arrow) and Andean thrust (blank arrow) that folds a previous Gondwanan thrust. The Andean thrust reactivates a previous Gondwanan thrust. La Jaula glacier cirque; B. Andean thrust deforming a Gondwanan thrust, cutting a Triassic dyke and superimposing the middle member of the El Plata Formation above its upper member. La Hollada glacier cirque; C. Andean back-thrusts superimposing the lower member of the El Plata Formation above the Choiyoi Group, which unconformably overlies it. Vallecitos Quebrada, southern slope of the Andresito peak. EPF: El Plata Formation; i: lower member; m: middle member; s: upper member; CHG: Choiyoi Group; Dashed white lines: Stratification traces. 


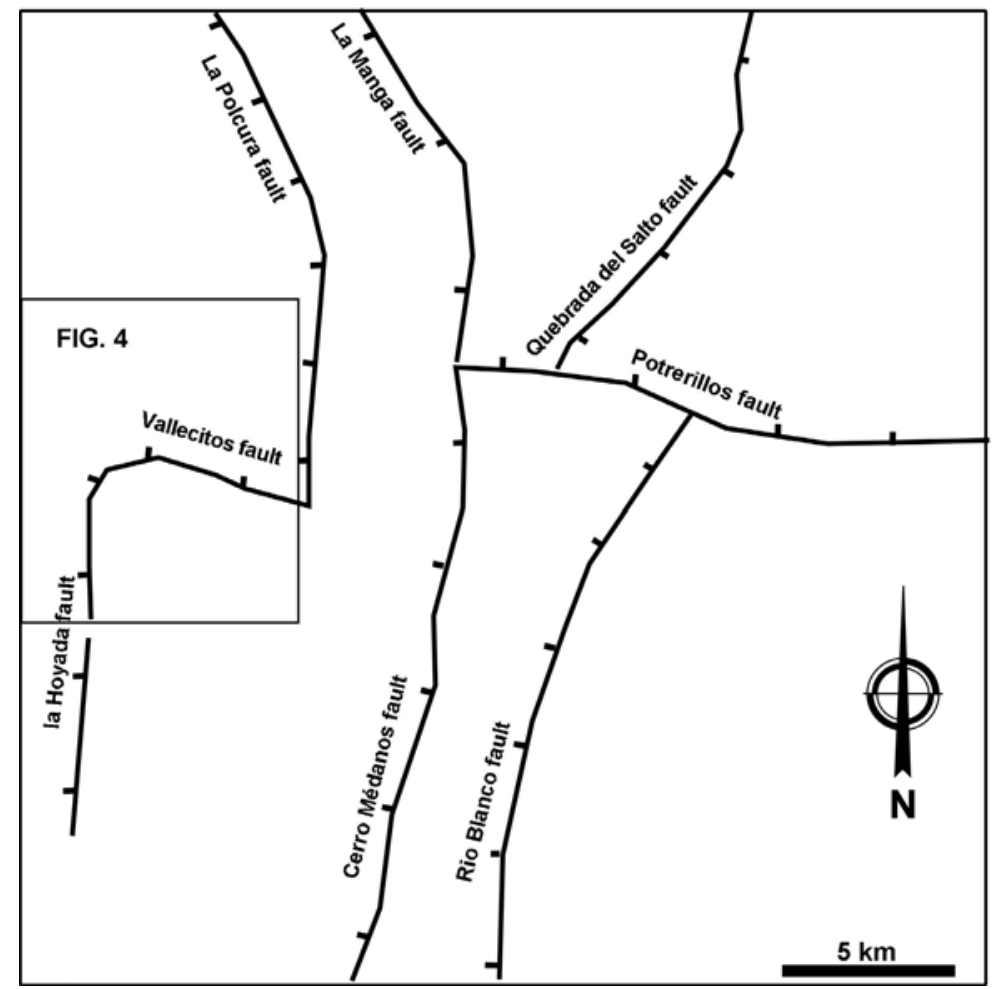

FIG. 10. Geological sketch showing the main faults of the Permian-Triassic extensional system of the Andean Orogenic Cycle.

fault in this paper, Fig. 2). Finally, in the hanging wall of the N-S trending Cerro Medanos fault, the thickness of the Choiyoi Group is around 2,000 m, the common thickness in the Frontal Cordillera, where it can exceed 4,000 m (Heredia et al., 2002).

\subsection{Andean compressive structures}

In the Cenozoic, the Cerro Arenal, Médanos and Río Blanco faults produced the main uplift of the Cordón del Plata massif juxtaposing the pre-Andean basement and the Neogene rocks (Cerro Médanos fault, Figs. 2, 3A and 7). The Andean compressive faults are usually subvertical and merge in a common detachment dipping to the west (Folguera et al., 2003, Giambiagi et al., 2010) (Fig. 7). Displacements of these faults range from hundreds of meters to kilometers (Fig. 7). As shown in the geological map and cross-sections (Figs. 2, 4 and 7), the Andean faults reactivated some Gondwanan thrusts and Mesozoic extensional structures. In this way, the La Hoyada-Vallecitos normal fault could also have been active during the Andean Orogeny as a lateral ramp, as indicated the absence of back-thrusts in the southern block. The Cenozoic deformation could also be responsible for the Potrerillos Fault reactivation as a lateral ramp of an Andean thrust. Such reactivation could cause the steep plunge of the folds axes in the Precordillera and its abrupt southern termination (Fig. 2).

\section{Proposal of Geodynamic Evolution during the Late Paleozoic}

In recent years, several models on the Late Paleozoic geodynamic evolution of the southern Central Andes have been published (Ramos et al., 2000; Davis et al., 2000; Ramos, 2004; Massonne and Calderón, 2008). In these models, the geodynamic evolution is linked to the accretion of the Chilenia terrane (Fig. 1) to the Gondwana margin, formed by the Cuyania terrane (Fig. 1) previously accreted during Silurian-Early Carboniferous times (Famatinian Orogenic Cycle). The subsequent development of a subduction in the western margin of the Chilenia terrane was mainly developed during de Gondwanan 
Orogenic Cycle in Late Carboniferous-Early Permian times (Rebolledo and Charrier, 1994).

New details of the geodynamic evolution of the southern Central Argentine Andes during the Late Paleozoic can be obtained from our study; based on the presence in the Cordón del Plata of three rock sets with different structural and metamorphic history, separated by two major unconformities (Figs. 2 and $6)$. Our data was completed and compared with that obtained by different authors in surrounding areas of the Cordillera Frontal and also in the Precordillera.

The main structures affecting the rocks of the Vallecitos beds in the Cordón del Plata must have been generated during the Famatinian Orogenic Cycle. The possible Devonian age of these rocks and their location in the eastern part of the Frontal Cordillera, suggest that their structures are related to the Chánic Orogeny of that cycle, produced by the accretion of Chilenia to the Gondwana margin, formed by the Cuyania terrane (Fig. 1), previously accreted in Late Devonian times (Ramos et al., 1984). This collision left remnants of Late Proterozoic-Silurian rocks with ophiolite affinities on the western side of the Precordillera, (Davis et al., 1999) that marked the separation (suture) between these two terranes (Fig. 1). If this interpretation is correct, Vallecitos beds should correspond to sediments deposited on the continental margin of Chilenia (Fig. 11A) while the coeval series in the Precordillera (Fig. 5) were deposited on the continental margin of Gondwana (Fig. 11A). The volcanic clasts in the Vallecitos beds point to the existence of an active volcanic area in the Chilenia terrain. This volcanism would imply a west-dipping subduction, in which the oceanic crust that separated the two continents was completely consumed under Chilenia (Davis et al., 1999; Gerbi et al., 2002; Giambiagi et al., 2009), although the separation between both continents should not have been very wide (Rapela, et al., 1998; Busquets et al., 2005). In addition, Tickyj (2011) describes Lower Devonian calc-alkaline granitoids (Fig. 11A) in the eastern part of the Frontal Cordillera (Cordón del Carrizalito), just south of the study area, which have been interpreted as belonging to a magmatic arc. In this context, the rocks of Vallecitos beds were deposited in the active margin of Chilenia, probably in a fore-arc basin associated with the subduction (Fig. 11A). It has not been possible to deduce the vergence of the Chanic structures in the study area. West-verging structures of this age (Fig. 11A) have been described in northern parts of the Frontal Cordillera (Heredia et al., 2002) and also further south (Tickyj et al., 2009). On the other hand the presence in the Frontal Cordillera, further to the south and east, of high-grade metamorphic rocks (Bjerg et al., 1990) and granitoids (Caminos et al., 1979; Tickyj, 2011) of Early Devonian to Early Carboniferous age, point to the presence of the Chanic Orogen hinterland in the eastern Frontal Cordillera. In contrast, the Chanic structures in the Central and Western Precordillera show a general vergence towards the east (Davis et al., 1999; Álvarez Marrón et al., 2006; Alonso et al., 2008) and the metamorphic grade increases westward (Von Gosen, 1992), as it might be expected from its location on the Gondwana passive margin (Alonso et al., 2008), prior to the collision of Chilenia (Fig. 11A).

On the other hand, no Chanic synorogenic rocks have been found in the study area, as in the rest of the Frontal Cordillera. However in the Precordillera, these rocks are well represented by the Early Carboniferous Angualasto Group (Limarino and Cesari, 1992, Limarino et al., 2006) (Fig. 6). The presence in this stratigraphic unit of conglomerates with volcanic and plutonic clasts of western provenance and Early Carboniferous age, represents the erosion of the magmatic arc from Chilenia during the Chanic Orogeny (Fig. 11B). The Chanic plutonic activity must be linked with the subduction in pre-collisional times and with the crustal thickening that occurred during the orogenic process, in syn-collisional times. The presence of low-grade regional metamorphism, scarce plutonism and westward verging structures in nearby areas, supports the conclusion that this sector of the Frontal Cordillera was located in the hinterland of the western segment of the Chanic Cordillera (Fig. 11B).

After the Gondwana-Chilenia collision, a new subduction zone developed on the western margin of accreted Chilenia (Ramos, 1988; Rebolledo and Charrier, 1994), beginning the Gondwanan Orogenic Cycle (Fig. 11C). In the Late Carboniferous, the sedimentation of the El Plata Formation took place in a back-arc extensional basin (Fig. 11C), representing the first Gondwanan pre-orogenic sequence (Mpodozis and Ramos, 1989; Fernández Seveso et al., 1993; Astini, 1996; Azcuy et al., 1999; Charrier et al., 2007). The Carboniferous rocks of the study area are part of the Río Blanco-Calingasta-Uspallata basin (Amos and Rollieri, 1965). The Protoprecordillera (Amos and 
w

E
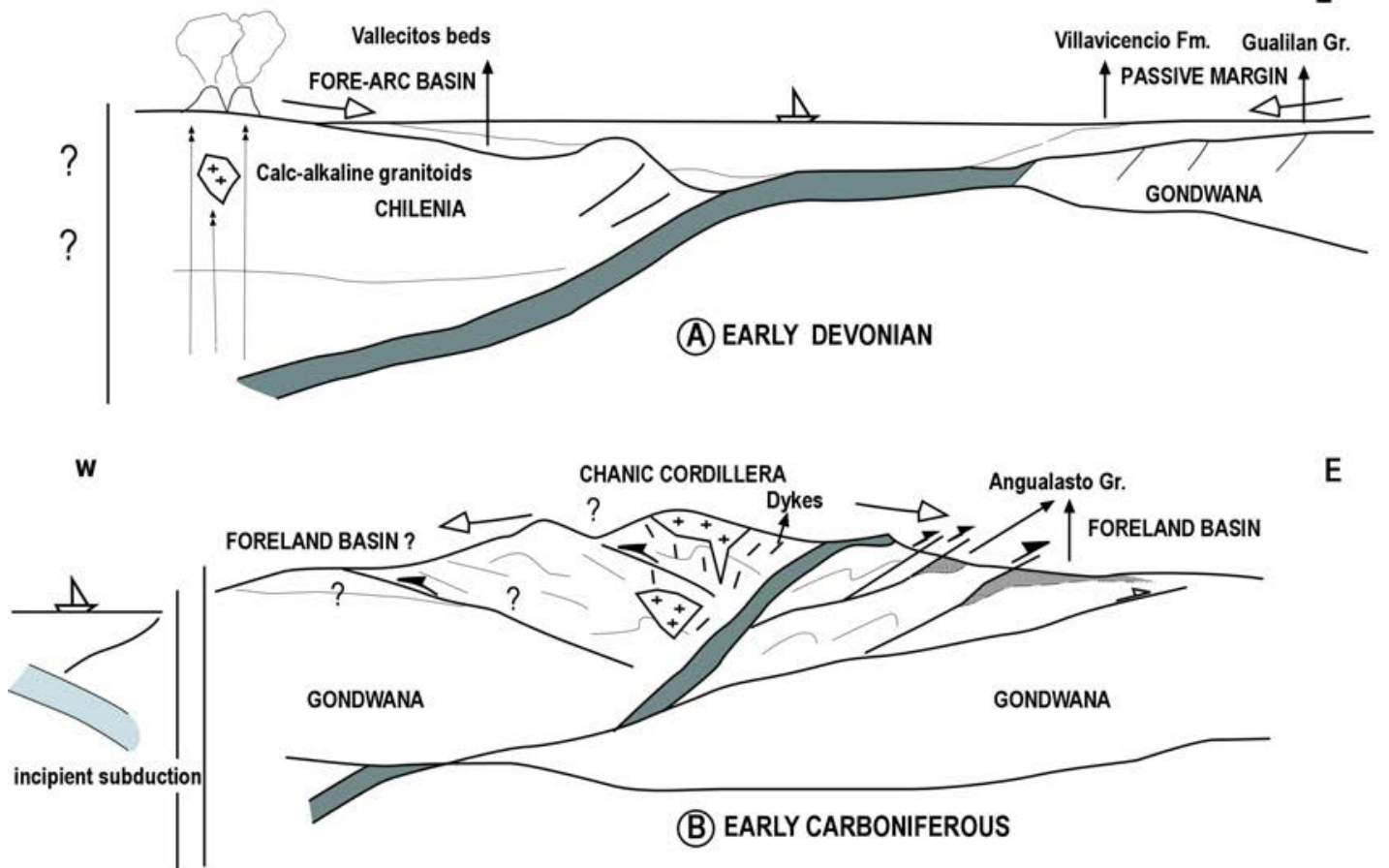

W incipient volcanic arc

BACK-ARC BASIN

E

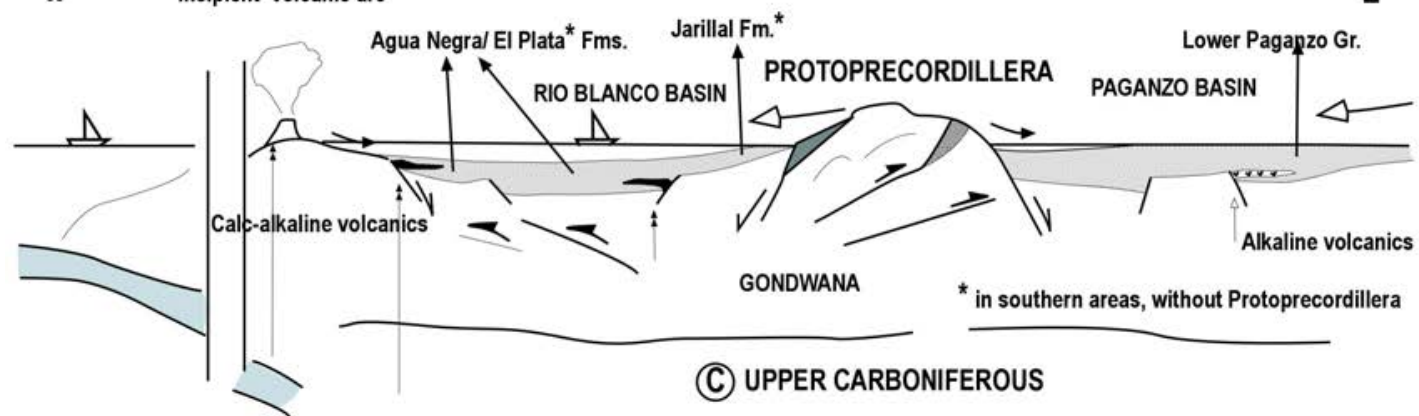

W

mature volcanic arc

San Ignacio Fm./ Rio Blanco $\mathrm{Cg}$.

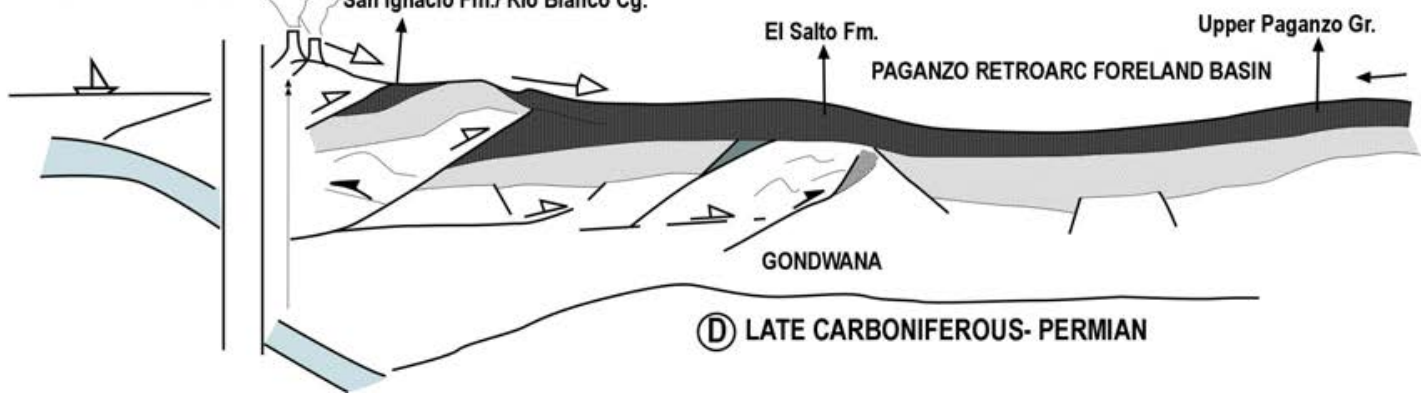

FIG. 11. Geodynamic evolution sketch of the Andes between $30^{\circ}$ and $33^{\circ} \mathrm{S}$ latitude, during Late Paleozoic times. Figures are not to escale. Blank Arrows: main areas of sediment supply. Black arrows: other areas of sediment supply; Fm: formation; Gr: group; Cg: conglomerates. 
Rollieri, 1965) (Fig. 11C) developed during most of the Late Carboniferous and appears to have been a horst-like topographic high that was inherited from the Chanic Cordillera and separated the Río Blanco basin from the Paganzo basin farther east (Azcuy and Morelli, 1970; Salfity and Gorustovich, 1983; López Gamundi et al., 1987; Azcuy, 1985; Fernández Seveso et al., 1993; Azcuy et al., 1999; Limarino y Spalletti, 2006; Limarino et al., 2006). The change in lithologic characteristics described earlier, of timestratigraphic equivalent rocks (i.e., Agua Negra, El Plata, and Jarillal Formations in Fig. 6) reflects the relative influence of this Protoprecordillera high, that appears to have become progressively less prominent to the south and was absent south of the study area. These Gondwanan pre-orogenic rocks are mainly sourced from the East, in the present-day Sierras Pampeanas (Limarino, 1987; Heredia et al., 2002). However, where the Protoprecordillera was present, it provided a local source of sediment. On the far west, in Río Blanco basin, a western source of sediment (from the volcanic arc) can be recognized, but it is rare because, the arc was not well developed at this time (Fig. 11C). Río Blanco basin probably began as an extensional back-arc feature that was initially filled largely with marine deposits. The pre-orogenic extensional character of this basin is compatible with the moderate calc-alkaline volcanism found in the Frontal Cordillera and Precordillera (Freije et al., 1999; Koukharsky et al., 2009) and the alkaline volcanism (Koukharsky et al., 2002) in eastern areas, away from the Gondwanic subduction zone (Paganzo Basin) (Fig. 11C). In the later phases of the Gondwanan Cycle (San Rafael orogenic phase of Late Carboniferous-Permian times) contractional deformation, with east-directed thrusts and folds, produced a retro-arc foreland basin that was filled with synorogenic continental deposits (Río Blanco Conglomerate in the Cordón del Plata area and San Ignacio Formation farther north). These synorogenic deposits (Fig. 6) contain clasts of volcanic origin and, only in the San Ignacio Formation, volcanic and volcano-sedimentary rocks sourced from the active volcanic arc. Moreover, the volcanic intercalations in these successions indicate that the volcanic arc remained active during the entire orogenic process (Fig. 11D). Except in the Paganzo Basin, the source area of the Gondwanan synorogenic deposits was located to the west, forming part of a retro-arc foreland basin that shows isolated outcrops at present (Busquets et al., 2005). The Protoprecordillera disappeared at this time (Fig. 11D), and the El Salto Formation, the Pircas Conglomerates and other equivalent synorogenic series (Fig. 6) were deposited in the Precordillera area (Fig. 11D).

Considering the deformation style and the absence of metamorphism and plutonism, the Frontal Cordillera can be interpreted as part of the foreland of the Gondwanan Orogen, which was far away from the subduction zone (Fig. 11D). Finally, the Choiyoi Group rests unconformably over all the rocks described above and represents the Permo-Triassic extensional episode (Ramos, 1988; Uliana et al., 1989; Llambias y Sato, 1990), which started the Andean Orogenic Cycle (Heredia et al., 2002).

\section{Acknowledgements}

We are grateful to reviewers F. Hogn, J. Kley and C. Schmidt, whose comments have improved the original manuscript and also to P.G. Masby for the English review. This work has been supported by CGL2006-12415-CO3/BTE and CGL2009-13706-CO3 projects (Spanish I+D+i Plan).

\section{References}

Alonso, J.L.; Gallastegui, J.; García-Sansegundo, J.; Farías, P.; Rodríguez-Fernández, L.R.; Ramos, V.A. 2008. Extensional tectonics and gravitational collapse in an Ordovician passive margin: The Western Argentine Precordillera. Gondwana Research 13: 204-215.

Álvarez-Marrón, J.; Rodríguez-Fernández, L.R.; Heredia, N.; Busquets, P.; Colombo, F.; Brown, D. 2006. Neogene structures overprinting Palaeozoic thrust systems in the Andean Precordillera at $30^{\circ} \mathrm{S}$ latitude. Journal of the Geological Society of London 163: 949-964.

Amenábar, C.; di Pasquo, M. 2008. Nuevos aportes a la palinología, cronología y paleoambientes de la Precordillera Occidental de Argentina: formaciones El Planchón, Codo (Devónico) y El Ratón (Mississippiano). Acta Geológica Lilloana 21 (1): 3-20.

Amos, A.J.; Rolleri, E.O. 1965. El Carbónico marino en el valle de Calingasta-Uspallata (San Juan-Mendoza). Boletín de Informaciones Petroleras 368: 50-71.

Astini, R.A. 1996. Las fases diatróficas del Paleozoico Medio en la Precordillera del oeste argentino. Evidencias estratigráficas. In Congreso Geológico Argentino, No. 13 y Congreso de Exploración de 
Hidrocarburos, No. 3. Actas 5: 509-526. Buenos Aires.

Azcuy, L. 1985. Late Carboniferous paleogeography and stratigraphy of Argentina. In Congreso Internacional de Estratigrafía y Geología del Carbonífero. No. 10, Actas 4: 281-293. Madrid.

Azcuy, L.; Carrizo, H.A.; Caminos, R. 1999. Carbonífero y Pérmico de las Sierras Pampeanas, Famatina, Precordillera, Cordillera Frontal y Bloque de San Rafael. In Geología Argentina (Caminos, R.; editor). Servicio Geológico Minero Argentino (SEGEMAR): 261-318. Buenos Aires.

Azcuy, C.L.; Morelli, J.R. 1970. Geología de la comarca Paganzo-Amaná, el Grupo Paganzo. Formaciones que lo componen y sus relaciones. Revista de la Asociación Geológica Argentina 25: 405-429.

Baldis, B.A.; Sarudiansky, R. 1975. El Devónico del noroeste de la Precordillera argentina. Revista de la Asociación Geológica Argentina 30: 301-329.

Baldis, B.A.; Peralta, S.H. 1999. Silúrico y Devónico de la Precordillera de Cuyo y Bloque de San Rafael. In Geología Argentina (Caminos, R.; editor). Servicio Geológico Minero Argentino (SEGEMAR): 215-238. Buenos Aires.

Bjerg, E.A.; Gregori, D.A.; Losada-Calderón, A.; Labadía C.H. 1990. Las metamorfitas del faldeo oriental de la Cuchilla de Guarguaraz, Cordillera Frontal, Provincia de Mendoza. Revista de la Asociación Geológica Argentina 45 (3-4): 234-245.

Busquets, P.; Colombo, F.; Heredia, N.; Sole de Porta, N.; Rodríguez Fernández, L.R.; Álvarez Marron, J. 2005. Age and tectonostratigraphic significance of the Upper Carboniferous series in the basement of the Andean Frontal Cordillera: Geodynamic implications. Tectonophysics 399: 181-194.

Caminos, R. 1965. Geología de la vertiente oriental del Cordón del Plata, Cordillera Frontal de Mendoza. Revista de la Asociación Geológica Argentina 20 (3): 351-392.

Caminos, R. 1979. Cordillera Frontal. In Simposio de Geología Regional de Argentina, No. 2 (Turner, J.C.M.; editor). Academia Nacional de Ciencias de Cordoba 1: 397-453.

Caminos, R.; Cordani, U.G.; Linares, E. 1979. Geología y geocronología de las rocas metamórficas y eruptivas de la Precordillera y Cordillera Frontal de Mendoza, República Argentina. In Congreso Geológico Chileno, No. 2, Actas: 43-60. Arica.

Casa, A.L. 2005. Geología y neotectónica del piedemonte oriental del Cordón del Plata en los alrededores de El
Salto. Trabajo Final de Licenciatura (Unpublished), Universidad de Buenos Aires: 157 p.

Charrier, R.; Pinto, L.; Rodríguez, M.P. 2007. Tectonostratigraphic evolution of the Andean Orogen in Chile. In The Geology of Chile (Moreno, T.; Gibbons, W.; editors). Geological Society of London: 21-114. London.

Cortés, J.M.; González-Bonorino, G.; Koukharsky, M.; Pereyra, F.; Brodtkorb, A. 1997. Hoja de la Carta Geológica de la República Argentina a escala 1:100.000 No. 3369-09, Uspallata. Servicio Geológico Minero Argentino (SEGEMAR): 243 p.

Davis, J.S.; Roeske, S.M.; McClelland, W.M.; Kay, S.M. 2000. Mafic and ultramafic cristal fragments of the SW Precordillera terrane and their bearing on tectonic models of the early Paleozoic in Western Argentina. Geology 28: 171-174.

Davis, J.S.; Roeske, S.M.; McClelland, W.C.; Snee, L.W. 1999. Closing the ocean between the Precordillera terrane and Chilenia: Early Devonian ophiolite emplacement and deformation in the SW Precordillera. In Laurentia-Gondwana Connections before Pangea (Ramos, V.A.; Keppie, J.D.; editors). Geological Society of America. Special Paper 336: 115-138.

Fauqué, L.; Cortés, J.M.; Folguera, A.; Etcheverría, M.; 2000. Avalanchas de rocas asociadas a neotectónica en el valle del río Mendoza, al sur de Uspallata. Revista de la Asociación Geológica Argentina 55 (4): 419-423.

Fernández Seveso, F.; Pérez, M.; Brisson, I.; Álvarez, L. 1993. Análisis de Cuenca: Técnicas aplicadas a la serie carbónico-pérmica de Paganzo. Boletín de Informaciones Petroleras 33: 77-107.

Folguera, A.; Etcheverria, M.; Pazos, P.; Giambiagi, L.; Cortés, J.M.; Fauqué, L.; Fusari, C.; Rodriguez, M.F. 2003. Hoja de la Carta Geológica de la República Argentina a escala 1:100.000 No 3369-15, Potrerillos. Servicio Geológico Minero Argentino (SEGEMAR): 262 p.

Fort, A. 1944. Estudio de las condiciones estratigráficas y tectónicas del pie oriental del Cerro del Plata (Mendoza). Tesis Doctoral (Inédita), Universidad Nacional de Córdoba: 220 p.

Freije, R.; Gregori, D.; Ponce, J. 1999. Hallazgo de facies turbidíticas y lavas en almohadilla (pillow lavas) en la Formación El Plata (Carbónico superior?), Cordillera Frontal, provincia de Mendoza. In Congreso Geológico Argentino, No. 14. Actas 1, Resúmenes: p. 61. Salta.

Gerbi, C.; Roeske, S.M.; Davis, J.S. 2002. Geology and structural history of the southwest Precordillera margin, northern Mendoza Province, Argentina. Journal of South American Earth Sciences 14: 821-835. 
Giambiagi, L.; Mescua, J; Folguera, A.; Martínez, A. 2010. Estructuras y cinemática de la deformación pre-Andina del sector sur de la Precordillera, Mendoza, Argentina. Revista de la Asociación Geológica Argentina 66 (1): 5-20.

Giambiagi, L.; Mescua, J.; Bechis, F.; Martínez, A.; Folguera, A. 2011. Pre-Andean deformation of the Precordillera southern sector, Southern Central Andes. Geosphere 7: 219-239.

González Bonorino, G. 1975. Sedimentología de la Formación Punta Negra y algunas consideraciones sobre la geología regional de la Precordillera de San Juan y Mendoza. Revista de la Asociación Geológica Argentina 30 (3): 223-246.

Groeber, P. 1938. Mineralogía y Geología. Espasa-Calpe Argentina: $492 \mathrm{p}$.

Groeber, P. 1946. Observaciones Geológicas a lo largo del meridiano 70. Hoja Chos Malal. Asociación Geológica Argentina, Serie C Reimpresiones 1: 5-36.

Gutiérrez, P.R. 1983. Geología del tramo medio de la quebrada del Agua Negra. Depto. de Iglesia, Provincia de San Juan. Trabajo Final de Licenciatura (Inédito), Universidad de Buenos Aires, Facultad de Ciencias Exactas y Naturales: 189 p.

Gutscher, M.A.; Spakman, W.; Bijwaard, H.; Engdahl, E.R. 2000. Geodynamic of flat subduction: seismicity and tomographic constraints from the Andean margin. Tectonics 19 (5): 814-833.

Harrington, H. 1941. Investigaciones geológicas en las Sierras de Villavicencio y Mal País, provincia de Mendoza. Ministerio de Agricultura de la Nación. Dirección de Minas y Geología, Boletín 49: 1-59.

Heredia, N.; Rodríguez Fernández, L.R.; Gallastegui, G.; Busquets, P.; Colombo, F. 2002. Geological setting of the Argentine Frontal Cordillera in the flat-slab segment (3000'to 31 $30^{\circ}$ 'S latitude). In Flat Subduction in the Andes (Ramos, V.; McNulty, B.; editors). Journal of South American Earth Sciences 15 (1): 79- 99.

Koukharsky, M.; Kleiman, L.; Etchevarría, M.; Quenardelle, S.; Bercowsky, F. 2009. Carboniferous retro-arc volcanism with submarine and subaerial facies at the western Gondwana margin of Argentina. Journal of South American Earth Sciences 27 (4): 299-308.

Koukharsky, M.; Brodtkorb, M.K.; Ramos, V.A.; Kay, S.M.; Leal, P.R. 2002. Magmatismo básico y ultrabásico del Neopaleozoico en las Sierras Pampeanas y regiones aledañas. In Congreso Geológico Argentino, No. 15, Actas 2: 105-110. El Calafate.

Limarino, C.O. 1987. Paleoambientes sedimentarios y paleogeografía de la sección inferior del Grupo Paganzo en el Sistema del Famatina. Anales de la Academia de Ciencias Exactas Físicas y Naturales 39: 149-178.

Limarino, C.O.; Césari, S. 1992. Reubicación estratigráfica de la Formación Cortaderas y definición del Grupo Angualasto (Carbonífero Inferior, Precordillera de San Juan). Revista de la Asociación Geológica Argentina 47: 61-72.

Limarino, C.O.; Spalletti, L.A. 2006. Paleogeography of the upper Paleozoic basins of southern South America: An overview. Journal of South American Earth Sciences 22 (3-4): 134-155.

Limarino, C.O.; Tripaldi, A.; Marensi, S.; Fauque, L. 2006. Tectonic, sea-level, and climatic controls on Late Paleozoic sedimentation in the western basins of Argentina. Journal of South American Earth Sciences 22 (3-4): 205-226.

Llambías, E.J.; Sato, A.M. 1990. El Batolito de Colangüil $\left(29^{\circ}-31^{\circ} \mathrm{S}\right)$, Cordillera Frontal de Argentina; estructura y marco tectónico. Revista Geológica de Chile 17 (1): 89-108.

Llambías, E.; Kleiman, L.; Salvarredi, J. 1993. El magmatismo gondwánico. In Geología y Recursos Naturales de Mendoza (Ramos, V.; editor). In Congreso Geológico Argentino, No. 12 y Congreso de Exploración de Hidrocarburos, No. 2, Relatorio I (6): 53-64. Mendoza.

López Gamundi, O.R.; Azcuy, C.L.; Cuerda, A.; Valencio, D.A.; Vilas, J.F. 1987. Cuencas Río Blanco y CalingastaUspallata. In El Sistema Carbonífero en la República Argentina (Archangelsky, S.; editor). Academia Nacional de Ciencias de Córdoba: 101-132. Cordoba.

Massonne, H.J.; Calderon, M. 2008. P-T evolution of metapelites from the Guarguaraz Complex, Argentina: evidence for Devonian crustal thickening close to the western Gondwana margin. Revista Geológica de Chile 35 (2): 215-231.

Mpodozis, C.; Ramos, V.A. 1989. The Andes of Chile and Argentina. In Geology of the Andes and its relation to Hydrocarbon and Mineral Resources (Eriksen, G. E.; Cañas Pinochet, M.T.; Reinemund, J.A.; editors) Circumpacific Council for Energy and Mineral Resources, Earth Sciences Series 11: 59-90.

Polanski, J. 1959. El bloque varíscico de la Cordillera Frontal de Mendoza. Revista de la Asociación Geológica Argentina 12 (3): 165-196.

Polanski, J. 1970. Carbónico y Pérmico en la Argentina. Eudeba, 2a. Edition 1978: 216 p. Buenos Aires.

Polanski, J. 1972. Descripción geológica de la Hoja 24 a-b (Cerro Tupungato), provincia de Mendoza, Dirección Nacional de Geología y Minería, Buenos Aires, Argentina. Boletín 128: 110 p. 
Ramos, V.A. 1988. The tectonic of the Central Andes: $30^{\circ}$ to $33^{\circ} \mathrm{S}$ latitude. In Processes in Continental Litospheric Deformation (Clark, S.; Burchfiel, D.; editors). Geological Society of America, Special Paper 218: 31-54.

Ramos, V.A. 2004. Cuyania, an Exotic Block to Gondwana: Review of a historical success and the present problems. Gondwana Research 7: 1009-1026.

Ramos V.A.; Escayola M.; Mutti D.I.; Vujovich G.I. 2000. Proterozoic-early Paleozoic ophiolites of the Andean basement of South America. Geological Society of America Special Paper 349: 331-349.

Ramos, V.A.; Jordan, T.A.; Allmendinger, R.W.; Kay, S.M.; Cortés, J.M.; Palma, M.A. 1984. Chilenia: un terreno alóctono en la evolución paleozoica de los Andes Centrales. In Congreso Geológico Argentino; No 9, Actas 2: 84-106. Buenos Aires.

Rapela, C.W.; Pankhurst, R.J.; Casquet, C.; Baldo, E.; Saavedra, J.; Galindo, C. 1998. Early evolution of the Proto-Andean margin of South America. Geology 26 (8): 707-710.

Rebolledo, S.; Charrier, R. 1994. Evolución del basamento paleozoico en el área de Punta Claditas, Región de Coquimbo, Chile $\left(31^{\circ}-32^{\circ} \mathrm{S}\right)$. Revista Geológica de Chile, 21 (1): 55-69.

Rolleri, E.O.; Criado, P. 1969. Geología de la provincia de Mendoza. Jornadas Geológicas Argentinas, No. 4, Actas 2: 1-60.
Salfity, J.; Gorustovich, S.A. 1983. Paleogeografía de la Cuenca del Grupo Paganzo, Paleozoico Superior. Revista de la Asociación Geológica Argentina 38 (3-4): 437-453.

Sessarego, H.L.F. 1988. Estratigrafía de las secuencias epiclásticas devónicas a triásicas aflorantes al norte del río San Juan y al oeste de la sierra del Tigre, provincia de San Juan. Tesis de Doctorado (Inédito), Universidad de Buenos Aires: 324 p.

Tickyj, H. 2011. Granitoides calcoalcalinos TardíoFamatinianos en el Cordón del Carrizalito, Cordillera Frontal, Mendoza. In Petrología Ígnea y Metamórfica, Congreso Geológico Argentino, No 18, Actas CD: 1-2. Neuquén

Tickyj, H.; Rodríguez Raising, C.; Cingolani, C.A.; Alfaro, M.; Uriz, N. 2009. Graptolitos ordovícicos en el Sur de la Cordillera Frontal de Mendoza. Revista de la Asociación Geológica Argentina 64 (2): 295-302.

Uliana, M.A.; Biddle, K.T.; Cerdan, J. 1989. Mesozoic extension and the formation of Argentine sedimentary basins. In Extensional tectonics and stratigraphy of the North Atlantic margins (Tankard, A.J.; Balkwill, H.R.; editors). American Association of Petroleum Geologists, Memoir 46: 599-614.

Von Gosen, W. 1992. Structural evolution of the Argentine Precordillera: the Rio San Juan section. Journal of Structural Geology 14: 643-667.

Manuscript received: June 30, 2010; revised/accepted: September 28, 2011; available online: November 08, 2011. 